\title{
EVALUASI KESESUAIAN PERKULIAHAN MICROTEACHING PENDIDIKAN FISIKA TERHADAP KKNI DI UIN SUNAN KALIJAGA YOGYAKARTA
}

\author{
Arina Izataki Fuady ${ }^{1)}$, Zuhdan Kun Prasetyo ${ }^{2)}$ \\ Program Studi Pendidikan Sains PPs UNY ${ }^{1)}$, Universitas Negeri Yogyakarta ${ }^{2)}$ \\ arina_fuady@yahoo.com ${ }^{1)}$, zuhdan@uny.ac.id ${ }^{2)}$
}

\begin{abstract}
Abstrak
Evaluasi kesesuaian perkuliahan microteaching Pendidikan Fisika terhadap KKNI di UIN Sunan Kalijaga ini dengan model stake menggunakan analisis deskriptif kuantitatif. Berdasarkan hasil analisis data diketahui (1) kesesuaian perencanaan pembelajaran yang disusun oleh dosen terhadap pencapaian KKNI pendidikan fisika sebesar $45,45 \%$ termasuk dalam kategori cukup, (2) kesesuaian pelaksanaan perkuliahan yang dilaksanakan terhadap pencapaian KKNI pendidikan fisika sebesar 75,34\% dengan terkategori sangat baik dan peran serta dosen terhadap pencapaian kemampuan mahasiswa terhadap KKNI sebesar 55,01\% dengan kategori cukup, serta (3) kesesuaian penilaian yang dilakukan dosen terhadap pencapaian KKNI pendidikan fisika sebesar 72,73\% dengan kategori baik.
\end{abstract}

Kata kunci: evaluasi, perkuliahan microteaching, KKNI.

\section{SUITABILITY EVALUATION OF PHYSICS EDUCATION MICROTEACHIG CLASS TO KKNI IN SUNAN KALIJAGA ISLAMIC UNIVERSITY}

\begin{abstract}
Evaluation of suitability evaluation of physics education microteachig class to KKNI in Sunan Kalijaga Islamic University was done by stake model with quantitave descriptive analysis. Based on data analysis indicate that (1) the suitability of planning class to the achievement of KKNI Level 6 phisics education at $45.45 \%$ ( enough categorized); (2) the suitability of the implementation of class held on the achievement KKNI Level 6 physics education viewed through the achievement of the student's ability to KKNI Level 6 at 75.34\% (very well categorized) and the role of the lecturer to the achievement of the students ability to KKNI Level 6 amounting to $55.01 \%$ (enough categorized); and (3) the conformity assessment of the achievement of the lecturers do KKNI Level 6 physical education by $72.73 \%$ (well categorized).
\end{abstract}

Key words: evaluation, microteaching class, KKNI 


\section{PENDAHULUAN}

Pendidikan tidak terlepas dari peran serta guru sebagai fasilitator dan mediator. Guru berperan untuk mengembangkan potensi peserta didik agar mereka akan tahu terhadap pengetahuan dan mampu untuk melakukan sesuatu (Mundilarto, 2010, p.4). Perkembangan IPTEK yang semakin pesat mengakibatkan ketidaksepadanan antara materi yang diajarkan di sekolah dengan kondisi dan kebutuhan di lapangan. Ketidaksepadanan pendidikan ini telah menjadi perhatian pemerintah dengan menyesuaikan kurikulum sekolah pada semua jenjang pendidikan (Suwarna et al, 2005, pp.89). Penyesuaian kurikulum ini mengakibatkan kompetensi guru dituntut untuk ikut berkembang sesuai dengan kurikulum yang berlaku. LPTK saling berlomba untuk mengembangkan pembelajaran yang mendukung pengembangan kompetensi calon pendidik yang disesuaikan dengan kebutuhan di lapangan. Salah satu LPTK yang dimaksud adalah Universitas Islam Negeri Sunan Kalijaga Yogyakarta.

UIN Sunan Kalijaga merupakan salah satu universitas di Daerah Istimewa Yogyakarta yang menawarkan program studi kependidikan. Berdasarkan visi, misi, dan tujuan Program Studi Pendidikan Matematika dan Sains yang di antaranya adalah menjadikan lulusannya sebagai pendidik yang profesional, Fakultas Sains dan Teknologi menyelenggarakan program Praktik Pembelajaran Mikro (microteaching) atau disingkat PPM yang dilanjutkan dengan praktik yang sesungguhnya di sekolah mitra pada Program Latihan Profesi atau disingkat PLP (Tim UIN, 2011, p.3).

Microteaching merupakan pembelajaran atas dasar kinerja yang tekniknya dilakukan dengan melatihkan komponen kompetensi dasar mengajar dalam proses pembelajaran agar calon pendidik mampu menguasai setiap komponen satu persatu atau beberapa komponen secara terpadu dalam situasi pembelajaran yang disederhanakan (Tim UNY, 2012, p.i). Selain untuk melatih kompetensi dasar mengajar, microteaching juga sebagai sarana latihan untuk tampil berani menghadapi kelas, mengendalikan emosi, serta ritme pembicaraan. Langkah ini dimaksudkan untuk memberikan pengalaman praktis tambahan calon pendidik sebelum mereka mulai praktik klinis mereka di kelas nyata (Ismail, 2011, p.1043). Selain itu pelaksanaan microteaching mampu memberi pandangan yang baru dan berbeda dalam menyusun perencanaan dan startegi pelaksanaan pembelajaran (Saban, A. \& Coklar, 2013, p.234).

Perkuliahan microteaching selalu dikembangkan sesuai dengan program studi serta kurikulum yang berlaku agar mampu memenuhi kebutuhan calon pendidik. Pembaharuan ini dikarenakan dalam pelaksanaan di lapangan, pendidik memiliki tuntutan sesuai dengan mata pelajaran yang diampu, salah satunya adalah mata pelajaran fisika. Pendidik mata pelajaran fisika dituntut untuk memberikan pemahaman konsep yang didasarkan pada praktikum.

Indikator yang harus dicapai setiap lulusan dan institusi pendidikan telah dimuat dalam draft KKNI Level 6. Berdasarkan draft KKNI Level 6 (uraian deskriptor spesifik) disebutkan bahwa learning outcomes yang harus dicapai lulusan program studi pendidikan fisika, yakni mampu melakukan tindakan reflektif untuk peningkatan kualitas pembelajaran, mampu menyelenggarakan penilaian dan evaluasi proses dan hasil belajar, mampu mengembangkan materi pelajaran fisika secara kreatif serta mampu membuat perencanaan pembelajaran (seperti silabus, RPP, LKPD dan perangkat evaluasi).

Berdasarkan hasil wawancara dengan Kaprodi pendidikan Fisika Fakultas Sains dan Teknologi UIN Sunan Kalijaga, diketahui bahwa dalam pelaksanaannya, perkuliahan di prodi ini telah disesuaikan dengan kurikulum 2013 (kurikulum yang berlaku di sekolah) dengan menekankan pada pencapaian Kerangka Kualifikasi Nasional Indonesia (KKNI), yang salah satunya adalah perkuliahan microteaching.

Hasil wawancara dengan kaprodi pendidikan fisika UIN Sunan Kalijaga menyatakan bahwa selama ini evaluasi perkuliahan microteaching dilakukan dalam bentuk pengisian kuesioner dan wawancara baik pada perwakilan mahasiswa maupun dosen pengampu, untuk mengetahui keterlaksanaan perkuliahan guna memperbaiki pelaksanaan perkuliahan pada periode selanjutnya. Kemampuan mahasiswa hanya dinilai menggunakan lembar penilaian yang terlampir pada buku pedoman microteaching. Hasil wawancara dengan dosen pembimbing perkuliahan diketahui bahwa buku pedoman mikro tahun 2013 tidak banyak mengalami perubahan dari tahun sebelumnya, walaupun kurikulum sekolah telah diperbaharui. Kondisi ini dapat diketahui terutama pada lembar penilaian mahasiswa. Hasil wawancara memunculkan pertanyaan mengenai kualitas perkuliahan microteaching yang didasarkan pada kurikulum 2013 dan KKNI. Perkuliahan ini didasarkan 
pada buku pedoman yang tidak banyak mengalami perubahan untuk disesuaikan dengan kurikulum baru yang diberlakukan dan ketercapaian KKNI. Selain itu kemampuan mahasiswa seharusnya dievaluasi menggunakan lembar penilaian yang harus disesuaikan dengan kurikulum yang berlaku.

Masalah yang diatasi dalam penelitian ini dibatasi pada perkuliahan microteaching yang didasarkan pada redesain kurikulum 2013 dan KKNI, serta cara dosen dalam menilai kemampuan mahasiswa menggunakan lembar penilaian.

Penelitian ini bertujuan untuk mendeskripsikan hasil evaluasi perkuliahan microteaching yang meliputi kesesuaian perencanaan perkuliahan yang telah disiapkan oleh dosen terhadap pencapaian KKNI Pendidikan Fisika, kesesuaian pelaksanaan perkuliahan yang dilaksanakan terhadap pencapaian KKNI Pendidikan Fisika, dan kesesuaian penilaian yang dilakukan dosen terhadap pencapaian KKNI Pendidikan Fisika.

Makna kesesuaian diartikan sebagai keselarasan yang dinilai dengan acuan yang telah ditetapkan. KKNI Pendidikan Fisika merupakan penjenjangan kualifikasi untuk lululan Program Studi S1 Pendidikan Fisika yang memuat kemampuan dalam memanfaatkan ICT dalam pembelajaran, kemampuan menggunakan peralatan laboratorium/kit pembelajaran, kemampuan menciptakan alat sederhana untuk kelancaran pembelajaran, kompetensi profesional, kompetensi pedagogogis, penguasaan terhadap metode penelitian pendidikan, penguasaan bimbingan dan konseling dalam pembelajaran, kemampuan menyusun perencanaan, pelaksanaan, dan penilaian pembelajaran, kompetensi kepribadian, serta kompetensi social. Selain itu ketercapaian indikator KKNI Pendidikan Fisika yang dilihat pada perkuliahan microteaching diketahui dari perencanaan perkuliahan yang disiapkan oleh dosen, pelaksanaan perkuliahan yang melibatkan mahasiswa dan dosen, serta indikator lembar penilaian yang disiapkan oleh dosen.

\section{METODE}

\section{Jenis dan Model Evaluasi}

Penelitian ini merupakan jenis penelitian evaluasi monitoring yang meliputi evaluasi terhadap perencanaan, pelaksanaan, dan penilaian perkuliahan microteaching. Model evaluasi yang digunakan dalam penelitian ini memodifikasi model evaluasi stake. Evaluasi pelaksa- naan perkuliahan microteaching ini meliputi evaluasi terhadap masukan yang diberikan oleh dosen yang dilihat ketika pembekalan perkuliahan, interaksi antara dosen dan mahasiswa selama perkuliahan, serta ketercapaian kemampuan mahasiswa terhadap KKNI Level 6 yang dilihat sebagai hasil pembelajaran.

\section{Waktu dan Tempat Penelitian}

Penelitian ini berlangsung selama perkuliahan semester 6 tahun akademik 2013/2014 di Prodi Pendidikan Fisika, Fakultas Sains dan Teknologi UIN Sunan Kalijaga Yogyakarta.

\section{Populasi dan Sampel Penelitian}

Populasi dalam penelitian ini meliputi 5 dosen pengampu perkuliahan microteaching dan 50 mahasiswa yang terbagi menjadi 5 kelas. Sampel dipilih melalui teknik cluster sampling untuk memperoleh 2 kelas dengan 2 dosen pengampu perkuliahan microteaching.

\section{Instrumen dan Teknik Pengumulan Data}

Pengumpulan data pada penelitian ini dilakukan dengan melakukan observasi pada saat pelaksanaan perkuliahan microteaching, membagikan angket kepada dosen dan mahasiswa, melakukan studi dokumen, serta melakukan wawancara kepada mahasiswa dan dosen. Untuk itu instrumen yang digunakan dalam penelitian ini meliputi lembar observasi untuk mahasiswa dan dosen, lembar analisis dokumen untuk mahasiswa dan dosen, lembar angket untuk mahasiswa dan dosen, serta lembar wawancara untuk mahasiswa dan dosen.

Untuk mengetahui kesesuaian perencanaan perkuliahan yang disiapkan oleh dosen terhadap KKNI, digunakan lembar analisis dokumen untuk dosen. Kesesuaian pelaksanaan perkuliahan terhadap KKNI dilihat melalui ketercapaian kemampuan mahasiswa terhadap KKNI dan peran serta dosen terhadap kemunculan kemampuan mahasiswa. Ketercapaain kemampuan mahasiswa diketahui melalui lembar observasi dan lembar analisis dokumen yang terkait dengan mahasiswa. Peran serta dosen terhadap kemampuan mahasiswa diketahui melalui lembar observasi untuk dosen. Untuk melihat kesesuaian antara penilaian yang dilakukan oleh dosen dengan KKNI dilakukan melalui studi dokumen milik dosen.

\section{Analisis Data}

Analisis data pada penelitian ini menggunakan analisis deskriptif kuantitaif. Data yang 
telah diolah menjadi bentuk persentase kemudian dikonversi menggunakan acuan kriteria skala lima. Data kemudian dideskripsikan sesuai dengan catatan dari hasil observasi maupun studi dokumentasi.

\section{HASIL DAN PEMBAHASAN}

\section{Perencanaan Perkuliahan Microteaching}

Perencanaan perkuliahan diketahui melalui wawancara dengan dosen pengampu perkuliahan dan studi dokumentasi. Hasil wawancara dengan dosen pembimbing diketahui bahwa dosen tidak dituntut untuk menyusun perencanaan perkuliahan. Dosen menggunakan buku panduan microteaching yang telah disiapkan oleh pusat pengembangan standar mutu akademik. Buku panduan tersebut memuat target perkuliahan, tugas dan kewajiban dosen dan mahasiswa dalam perkuliahan microteaching, tahapan yang harus dilakukan pada pelaksanaan perkuliahan microteaching, serta aspek yang harus dinilai oleh dosen.

Dosen sebagai supervisor dalam perkuliahan merupakan unsur penting dalam setiap latihan praktek mengajar. Sebagai pengelola pembelajaran, supervisor bukan hanya berfungsi membantu calon pendidik untuk mencapai tujuan latihan, tetapi juga melakukan evaluasi tentang efektivitas dari program latihan tersebut secara keseluruhan. Peran supervisor dalam latihan pengajaran mikro meliputi seluruh tahap dari prosedur pelaksanaannya (La Sulo et al., 1983, pp.22-23). Prosedur pelaksanaan ini merupakan kegiatan belajar sesuai dengan perencanaan yang telah ditetapkan (Wati, 2014, p.14). Dosen harus mengetahui target yang hendak dicapai, serta alasan penyampaian pokok bahasan (Afifudin, 2012, pp.83-84). Dosen harus menyusun perencanaan perkuliahan yang berisi kegiatan yang akan dilakukan dalam proses pembelajaran.

Buku panduan microteaching telah disusun oleh lembaga khusus yang ditugasi, namun dalam pelaksanaannya, dosen lebih berperan. Dosen yang tidak menyusun perencanaan mengakibatkan kurang memahami kegiatan yang semestinya dilakukan.

Hasil studi dokumentasi diketahui bahwa aspek yang termuat dalam buku panduan di antaranya telah berupa uraian deskriptor spesifik KKNI Level 6 yang memuat target perkuliahan. Persentase kesesuaian target perkuliahan microteaching terhadap KKNI Level 6 di LPTK tersebut mencapai 45,45\% dengan kategori cukup.

\section{Pelaksanaan Perkuliahan Microteaching}

Evaluasi pelaksanaan perkuliahan meliputi keterlaksanaan perkuliahan microteaching, kesesuaian kemampuan mahasiswa dengan uraian deskriptor spesifik KKNI Level 6, dan peran serta dosen untuk memunculkan kemampuan mahasiswa yang sesuai dengan uraian deskriptor spesifik KKNI Level 6.

\section{Keterlaksanaan Perkuliahan Microteaching}

Perkuliahan microteaching meliputi pembekalan yang dilanjutkan dengan pelaksanaan perkuliahan microteaching. Berdasarkan hasil wawancara diketahui bahwa pembekalan perkuliahan dilakukan oleh masing-masing dosen pembimbing microteaching. Materi yang disampaikan pada pembekalan meliputi perkenalan diri dari dosen pembimbing, menjelaskan hak dan kewajiban mahasiswa selama melaksanakan perkuliahan microteahing, penyesuaian jadwal perkuliahan, serta persiapan teknik pelaksanaan perkuliahan. Berdasarkan hasil observasi diketahui seluruh indikator pada aspek pembekalan perkuliahan yang telah terlaksana dengan sangat baik (100\%). Data ini didukung dengan hasil angket untuk dosen yang menyatakan bahwa persentase kemunculan untuk aspek pembekalan sebesar $100 \%$ (sangat baik). Data ini sedikit berbeda dengan hasil angket dari mahasiswa yang menyatakan bahwa persentase kemunculan untuk aspek pembekalan yang sebesar $94,74 \%$ (sangat baik).

Hasil penyesuaian pembekalan perkuliahan yang dilakukan dengan pembekalan perkuliahan yang diacu dalam penelitian ini diketahui bahwa pembekalan perkuliahan yang dilakukan belum optimal. Kondisi ini ditunjukkan dengan tidak munculnya observasi pembelajaran di sekolah oleh mahasiswa dan tidak munculnya diskusi antara dosen dengan mahasiswa mengenai hasil observasi pembelajaran di sekolah.

Berdasarkan hasil wawancara diketahui bahwa mahasiswa melakukan observasi pembelajaran di sekolah pada saat menempuh mata kuliah strategi pembelajaran fisika sebagai bekal pelaksanaan mata kuliah tersebut. Sebagai pembimbing perkuliahan microteaching, seharusnya dosen memiliki tugas membimbing latihan keterampilan dasar mengajar secara terbatas dan terpadu, membimbing observasi di tempat praktik mengajar, memberikan remedial terhadap mahasiswa yang belum dapat mencapai nilai 
minimal yang dipersyaratkan, serta memberi supervisi klinis kepada mahasiswa untuk meningkatkan kualitas kompetensi dasar mengajar (Sukaswanto, 2013, p.240).

Hasil observasi menunjukkan bahwa dosen berperan dalam mengevaluasi hasil latihan mengajar mahasiswa dan memberikan feed back, serta memberikan kesempatan kepada mahasiswa dalam melakukan latihan mengajar. Sebagian dosen pembimbing tidak memberikan kesempatan kepada mahasiswa secara menyeluruh untuk memberikan feed back terhadap mahasiswa lain yang telah melakukan latihan mengajar. Dosen pembimbing jarang memberikan contoh secara langsung. Dosen lebih sering memberikan masukan kepada mahasiswa tentang cara bersikap dibandingkan mencontohkannya. Berdasarkan hasil wawancara diketahui bahwa tidak semua dosen mewajibkan mahasiswa untuk melakukan bimbingan dalam membuat persiapan pembelajaran. Sebagian dosen melakukan bimbingan persiapan pembelajaran jika ada mahasiswa menginginkannya.

Hasil observasi pelaksanaan pada mahasiswa menunjukkan bahwa mahasiswa telah berpakaian sopan dan rapi, serta menghias diri sesuai dengan etika pendidik. Sebagian mahasiswa masih kesulitan dalam melaksanakan latihan praktik pembelajaran sesuai dengan perencanaan yang telah dibuat. Kondisi ditunjukkan oleh ketidaksesuaian antara waktu latihan praktik pembelajaran dengan perencanaan pembelajaran yang dibuat, serta terdapat tahapan pembelajaran yang tidak dilakukan.

Mahasiswa memberikan feed back kepada mahasiswa lain apabila dosen memberikan kesempatan kepada mahasiswa tersebut. Salah satu dosen hanya memberikan mahasiswa untuk melakukan praktek pembelajaran sebanyak 3 kali dengan durasi waktu maksimal 20 menit. Dosen yang lain memberikan kesempatan melakukan praktek pembelajaran yang lebih banyak untuk mahasiswa yang dirasa masih kurang. Mahasiswa membuat perencanaan pembelajaran sebelum melaksanakan latihan praktik pembelajaran, namun tidak semua mahasiswa mengkonsultasikannya kepada dosen pembimbing. Sebagian mahasiswa mengkonsultasikan perencanaan pembelajaran yang dibuatnya satu hari sebelum melaksanakan latihan praktik pembelajaran. Kondisi ini dikarenakan dosen pembimbing mengharuskan mahasiswa untuk melakukan konsultasi perencanaan pembelajaran yang akan digunakan pada latihan praktik pembelajaran.

\section{Ketercapaian Deskriptor KKNI Level 6}

Ketercapaian kemampuan mahasiswa terhadap uraian deskriptor spesifik KKNI level 6 diketahui melalui observasi mahasiswa selama melakukan latihan praktik pembelajaran dan studi dokumentasi terhadap perencanaan yang dibuat untuk melakukan latihan praktik pembelajaran. Hasil observasi dan studi dokumentasi diketahui ketercapaian kemampuan mahasiswa terhadap uraian deskriptor spesifik KKNI Level 6 sebesar 75,34\% dengan kategori sangat baik.

Hasil analisis data penelitian menggambarkan kemampuan mahasiswa dalam memanfaatkan ICT dalam pembelajaran dengan capaian sebesar $84,72 \%$ dengan kategori sangat baik. Data ini didukung dengan hasil angket untuk mahasiswa yang menggambarkan kemampuan mahasiswa dalam memanfaatkan ICT dalam pembelajaran sebesar dengan ncapaian $100 \%$ dengan kategori sangat baik.

Latihan praktik pembelajaran mahasiswa telah menunjukkan kemampuannya dalam mengoperasikan media pembelajaran berbasis ICT dan kemampuan menerapkan pembelajaran berbasis media audio, visual, atau audio visual. Data ini ditunjukkan melalui penggunaan media pembelajaran berbentuk microsoft powerpoint, macromedia flash, dan media player classic. Mahasiswa memadukan penggunaan berbagai media tersebut dalam pembelajaran, misalnya dalam menyampaikan susunan materi dengan microsoft powerpoint, menampilkan contoh pengaplikasian materi media player classic, dan menampilkan penyelesaian latihan soal dengan menggunakan macromedia flash.

Kemampuan mahasiswa dalam menciptakan alat sederhana untuk kelancaran pembelajaran fisika diketahui melalui observasi terhadap mahasiswa. Hasil obervasi diketahui mengenai kemampuan mahasiswa dalam menciptakan alat sederhana untuk kelancaran pembelajaran dengan capaian $68,61 \%$ dengan kategori baik. Data angket mahasiswa menyatakan bahwa kemampuan mahasiswa dalam menciptakan alat sederhana untuk kelancaran pembelajaran mencapai 89,47\% dengan kategori sangat baik.

Hasil observasi diketahui bahwa mahasiswa mampu membuat peralatan laboratorium sederhana seperti alat praktikum bandul matematis dari tali, kayu sebagai dudukan, dan plastisin sebagai pemberat serta alat praktikum pompa hidrolik sederhana dari papan sebagai dudukan, suntikan, dan selang. Mahasiswa juga mampu memanfaatkan potensi lokal untuk 
dijadikan alat peraga dalam pembelajaran seperti seruling kayu dan peluit kayu sebagai alat peraga untuk materi resonansi; tisu, spidol, gelas dan air untuk melatih mahasiswa melakukan penyelidikan IPA dengan eksperimen kapilaritas; penghapus papan tulis dan mobil-mobilan sebagai alat peraga tumbukan, serta penggunaan air, kayu, balon karet, botol, dan toples sebagai alat peraga untuk menjelaskan sifat fluida. Hasil wawancara diketahui bahwa pada semester sebelumnya mahasiswa telah menempuh mata kuliah media pembelajaran fisika, yang dalam pelaksanaannya menuntut mahasiswa untuk membuat media pembelajaran yang dikumpulkan pada akhir perkuliahan. Berbasis mata kuliah tersebut mahasiswa memiliki bekal untuk menciptakan alat peraga sederhana sebagai pendukung pelaksanaan pembelajaran.

Kompetensi profesional mahasiswa diketahui melalui observasi terhadap mahasiswa dan studi dokumentasi. Hasil analisis data untuk kompetensi profesional menunjukkan persentase kemunculan sebesar 85,62\% dengan kategori sangat baik. Data ini sedikit berbeda dengan data hasil angket yang menunjukkan kemunculan kompetensi profesional sebesar 78,95\% dengan kategori sangat baik.

Sebagian mahasiswa telah menunjukkan penguasaan materi, struktur, konsep, dan pola berpikir keilmuan yang mendukung materi yang disampaikan. Hasil studi dokumentasi juga diketahui bahwa mahasiswa mampu merancang perencanaan pembelajaran sesuai dengan KI/ $\mathrm{KD}$, mampu mengembangkan materi pelajaran fisika secara kreatif yang ditunjukkan dari sintaks pembelajaran dan media pembelajaran yang akan digunakan, mampu mengembangkan materi yang akan disampaikan dengan kondisi nyata di lapangan, serta menggunakan metode yang sesuai dengan materi yang akan disampaikan. Berdasarkan hasil wawancara diketahui bahwa mahasiswa belum menguasai semua materi fisika yang akan diajarkan pada pembelajaran nyata di sekolah. Untuk melaksanakan latihan praktik pembelajaran, mahasiswa memilih materi yang dirasanya mudah dan dipahami oleh mahasiswa.

Persentase kemunculan untuk kompetensi pedagogis mahasiswa sebesar $69,44 \%$, dengan kategori baik. Data ini berbeda dengan hasil angket mahasiswa yang menunjukkan bahwa untuk kompetensi pedagogis dengan persentase kemunculan sebesar 85,62\% dengan kategori sangat baik.
Hasil studi dokumentasi terhadap mahasiswa diketahui bahwa sebagian besar mahasiswa telah menguasai beberapa metode pembelajaran yang mendidik. Kondisi ini ditunjukkan dengan penggunaan metode pada dua praktik pembelajaran yang dilakukan mahasiswa. Mahasiswa telah mampu mengembangkan pembelajaran sesuai dengan kurikulum 2013. Kemampuan ini ditunjukkan oleh kemampuan memilih metode yang akan dipakai dalam pembelajaran serta langkah pembelajaran yang berisi kegiatan yang melibatkan peserta didik. Sebagian besar mahasiswa telah memfasilitasi pengembangan potensi peserta didik dengan penggunaan berbagai media pembelajaran. Selain itu mahasiswa telah mampu menyiapkan penilaian dan evaluasi proses dan hasil belajar. Data ini ditunjukkan dengan adanya latihan soal yang dibuat mahasiswa yang akan digunakan sebagai evaluasi pembelajaran. Hasil wawancara diketahui bahwa pada semester sebelumnya, mahasiswa menempuh mata kuliah psikologi pendidikan dan strategi pembelajarn fisika. Penguasaan indikator spesifik kompetensi pedagogis dapat diperoleh melalui perkuliahan tersebut.

Untuk mengetahui penguasaan metode penelitiaan pendidikan mahasiswa dilakukan observasi terhadap mahasiswa. Hasil observasi diketahui besarnya persentase kemunculan untuk penguasaan metode penelitiaan pendidikan mahasiswa sebesar $64,44 \%$ dengan kategori baik. Hasil ini sedikit berbeda dengan hasil angket mahasiswa yang menunjukkan bahwa persentase kemunculan penguasaan metode penelitiaan pendidikan sebesar $73,68 \%$ dengan kategori baik.

Kemampuan mahasiswa dalam menguasai metode penelitian pendidikan ditunjukkan dengan memberikan masukan kepada teman sejawat yang telah melaksanakan latihan praktik pembelajaran. Kemampuan tersebut muncul dikarenakan dosen menuntut mahasiswa untuk memberikan komentar dan masukan kepada mahasiswa lain yang melaksanakan praktik pembelajaran. Tidak semua dosen pembimbing menuntut setiap mahasiswanya untuk berlatih memberikan komentar dan masukan kepada mahasiswa lain yang melaksanakan praktik pembelajaran.

Penguasaan pengetahuan bimbingan dan konseling mahasiswa diketahui melalui observasi mahasiswa selama melaksanakan praktik pembelajaran. Hasil observasi menggambarkan persentase kemunculan untuk pengusaan pengetahuan bimbingan dan konseling mahasiswa 
sebesar $27,77 \%$ dengan kategori kurang. Data ini berbeda dengan hasil angket mahasiswa yang menunjukkan bahwa persentase kemunculan untuk pengusaan pengetahuan bimbingan dan konseling mahasiswa yang sebesar 78,95\% dengan kategori sangat baik.

Hasil observasi memberi gambaran bahwa sebagian mahasiswa mampu memberikan bimbingan bagi peserta didik yang mengalami kesulitan dalam pembelajaran. Kemampuan mahasiswa dalam memberikan solusi yang tepat bagi peserta didik jarang sekali muncul. Berdasarkan hasil wawancara diketahui bahwa jarang terlihatnya kemampuan mahasiswa dikarenakan satu mahasiswa dengan mahasiswa lain merasa harus saling memudahkan jalannya praktik pembelajaran mikro yang dilakukan dengan tidak memberikan pertanyaan yang menyulitkan.

Kemampuan mahasiswa dalam menyusun perencanaan, pelaksanaan, dan penilaian pembelajaran diketahui melalui observasi dan studi dokumentasi. Analisis data hasil observasi dan studi dokumentasi diketahui persentase kemunculan untuk kemampuan mahasiswa dalam menyusun perencanaan, pelaksanaan, dan penilaian pembelajaran sebesar $88,05 \%$ dengan kategori sangat baik. Hasil ini sedikit berbeda dengan hasil angket yang menunjukkan persentase kemunculan untuk kemampuan mahasiswa dalam menyusun perencanaan, pelaksanaan, dan penilaian pembelajaran sebesar $85,96 \%$ (sangat baik).

Hasil observasi mengilustrasikan bahwa sebagian mahasiswa telah mampu melaksanakan pembelajaran sesuai dengan perencanaan pembelajaran yang telah dibuat. Beberapa mahasiswa kesulitan dalam membagi waktu dalam pelaksanaan pembelajaran sesuai dengan perencanaan yang telah dibuat. Mahasiswa mengalami kesulitan dikarenakan adanya rekan mahasiswa yang berperan menjadi peserta didik yang aktif bertanya. Berdasarkan lembar analisis dokumen diketahui bahwa mahasiswa telah mampu membuat perencanaan pembelajaran. Mahasiswa membuat perencanaan pembelajaran yang disertai lembar kegiatan peserta didik, soal latihan, serta lembar penilaian peserta didik. Hasil wawancara menggambarkan bahwa mahasiswa tidak menyusun silabus pembelajaran, dikarenakan sesuai kurikulum 2013 pemerintah telah menyiapkan silabus pembelajaran.

Kompetensi kepribadian diketahui melalui observasi terhadap mahasiswa. Hasil observasi menggambarkan persentase kemumculan untuk kompetensi kepribadian mahasiswa sebesar $81,82 \%$ dengan kategori sangat baik. Hasil ini sedikit berbeda dengan hasil angket mahasiswa yang menunjukkan persentase kemumculan untuk kompetensi kepribadian mahasiswa sebesar $81,05 \%$ dengan kategori sangat baik.

Hasil observasi menggambarkan bahwa mahasiswa telah menggunakan bahasa yang sopan dan santun dalam praktik pembelajaran. Sebagian besar mahasiswa telah mampu bersikap berwibawa serta arif dan dewasa pada saat berperan sebagai pendidik dalam praktik pembelajaran. Kemampuan mahasiswa untuk bersikap bijaksana dalam memberikan solusi pada peserta didik jarang terlihat. Kondisi ini dikarenakan jarang mahasiswa yang berperan sebagai pendidik untuk bertanya. Sebagian besar mahasiswa merasa percaya diri ketika tampil sebagai pendidik dalam praktik pembelajaran dan bersikap bertanggung jawab sebagai pendidik.

Kompetensi sosial mahasiswa diketahui melalui observasi terhadap mahasiswa. Berdasarkan hasil observasi diketahui persentase kemunculan untuk kompetensi sosial mahasiswa sebesar 91,37\% dengan kategori sangat baik. Hasil ini sedikit berbeda dengan hasil angket mahasiswa yang menunjukkan persentase kemunculan kompetensi sosial mahasiswa sebesar $89,47 \%$ (sangat baik).

Hasil observasi terhadap mahasiswa diketahui bahwa sebagian besar mahasiswa telah mampu bertindak adil dengan tidak membedakan peserta didik maupun teman sejawat. Kondisi ini ditunjukkan oleh mahasiswa yang berperan sebagai pendidik dengan melakukan observasi dan bimbingan kepada semua mahasiswa yang berperan sebagai peserta didik. Mahasiswa yang berperan sebagai pendidik berani menunjuk mahasiswa yang berperan sebagai peserta didik secara acak dan menyeluruh. Sebagian besar mahasiswa telah mampu berkomunikasi efektif dengan peserta didik maupun teman sejawat. Kondisi ini terlihat ketika mahasiswa yang berperan sebagai pendidik mampu memberikan penjelasan yang dapat dipahami oleh rekan mahasiswa yang berperan sebagai peserta didik ketika melakukan diskusi maupun menjawab pertanyaan.

Kemampuan beradaptasi dengan lingkungan pembelajaran telah ditunjukkan oleh seluruh mahasiswa. Perkuliahan microteaching pendidikan fisika di UIN Sunan Kalijaga menempati 3 ruang kelas di laboratorium Saintek, dan dilakukan perputaran kelas setiap 1 bulan 
sekali. Langkah ini mampu memunculkan kemampuan mahasiswa dalam beradaptasi dengan lingkungan pembelajaran.

\section{Peran Dosen terhadap Ketercapaian Kemampuan}

Peran dosen diketahui melalui observasi terhadap dosen selama mahasiswa melaksanakan pelatihan praktik pembelajaran. Peran dosen terhadap pencapaian kemampuan mahasiswa sebesar 55,01\% dengan kategori cukup. Hasil ini tidak sesuai dengan hasil angket yang menyatakan bahwa peran serta dosen terhadap ketercapaian kemampuan mahasiswa mencapai $97,92 \%$ dengan kategori sangat baik.

Dosen telah memberikan feedback kepada mahasiswa terhadap permasalahan yang dimunculkan oleh mahasiswa dalam praktik pembelajaran. Dosen sangat jarang memberikan bimbingan terhadap permasalahan lain yang mungkin dapat dilaksanakan dalam praktik pembelajaran maupun dalam pembelajaran nyata di sekolah. Dosen memberikan bimbingan terhadap alternatif pemilihan metode pembelajaran yang bisa dipakai selain metode pembelajaran yang telah digunakan dalam praktik pembelajaran. Berdasarkan hasil wawancara terhadap dosen pembimbing diketahui bahwa dosen pembimbing hanya bertugas untuk mendampingi mahasiswa dalam melaksanakan praktik pembelajaran. Mahasiswa dianggap sudah menguasai semua kemampuan calon pendidik melalui mata kuliah prasyarat dan mata kuliah pendukung perkuliahan microteaching. Sebagai supervisor, selama proses pengajaran mikro, dosen diharuskan secara aktif membimbing dan mengarahkan mahasiswa agar memiliki pengalaman mengajar yang memadai (Sudiyatno dan Nuryanto, 2009, pp.3-4).

\section{Penilaian Perkuliahan Microteaching}

Penilaian perkuliahan microteaching diketahui melalui wawancara terhadap dosen untuk melihat aspek penilaian perkuliahan microteaching. Lembar analisis dokumen digunakan untuk mengetahui keseuaian antara indikator penilaian terhadap KKNI Level 6. Lembar observasi keterlaksanaan untuk mengetahui keterlaksanaan dosen dalam melakukan penilaian terhadap mahasiswa.

Berdasarkan hasil wawancara diketahui bahwa dosen melakukan penilaian terhadap mahasiswa meliputi penilaian terhadap rencana pembelajaran mahasiswa, keterampilan dasar mengajar mahasiswa, serta kompetensi mahasis- wa. Penilaian ini sesuai dengan lembar penilaian yang telah disiapkan dan dilampirkan dalam buku panduan pembelajaran mikro yang menjadi pedoman untuk pelaksanaan perkuliahan microteaching. Data ini sedikit berbeda dengan tujuan dan target perkuliahan yang hanya memuat kompetensi pedagogis, profesional, pribadi dan sosial serta penjabaran masing-masing kompetensi. Evalusi (penilaian) diperlukan untuk mengukur tercapai atau tidaknya tujuan interaksi edukatif dalam proses pembelajaran (Asril, 2011, p.2). Penilaian merupakan bagian yang tidak dapat dipisahkan dalam proses pembelajaran yang digunakan sebagai usaha untuk melihat keberhasilan proses pembelajaran yang ditunjukkan dalam bentuk nilai dan juga digunakan sebagai penilaian terhadap usaha dalam rangka perbaikan penampilan (Juliantine, 2012, p.1). Penilaian dapat menghasilkan tindakan yang meningkatkan pembelajaran atau meningkatkan hasil belajar. Penilaian diharapkan menghasilkan informasi sebanyak mungkin, yang relevan dengan pembelajaran, baik informasi formal maupun informasi informal (Erlina, 2012, p.2). Untuk meningkatkan kualitas pembelajaran praktek, penilaian diwujudkan melalui proses interaksi antara guru dan peserta didik (Earl \& Giles, 2011, p.11).

Berdasarkan studi dokumentasi diketahui persentase kesesuaian antara indikator penilaian terhadap KKNI Level 6 yang sebesar 72,73\%, dengan kategori baik. Hasil observasi mengenai keterlaksanaan perkuliahan diketahui bahwa dosen pembimbing telah melakukan penilaian perkuliahan. Langkah tersebut didukung oleh lembar angket dosen yang menyatakan bahwa dosen telah melakukan penilaian perkuliahan dengan persentase kemunculan sebesar $100 \%$. Penilaian dilakukan oleh dosen selama mahasiswa melakukan praktik pembelajaran.

\section{Keterbatasan Penelitian}

Keterbatasan dalam penelitian ini adalah jumlah handycam yang digunakan untuk merekam hanya satu buah, sehingga jangkauan rekaman kurang menyeluruh. Selain itu instrumen penelitian yang digunakan hanya divalidasi oleh satu dosen ahli, setiap mahasiswa dan dosen hanya diamati oleh satu observer, serta tidak diketahui karakteristik masingmasing kelompok mahasiswa yang menjadi sampel dalam penelitian ini. 


\section{SIMPULAN DAN SARAN}

\section{Simpulan}

Berdasarkan deskripsi hasil penelitian dan pembahasan dapat ditarik kesimpulan mengenai evaluasi perkuliahan micoteaching pendidikan fisika terhadap KKNI di UIN Sunan Kalijaga Yogyakarta. Kesesuaian perencanaan perkuliahan yang dilihat dari buku panduan pembelajaran mikro terhadap KKNI pendidikan fisika terkategori cukup yang didasarkan pada persentase kemunculan uraian deskriptor KKNI sebesar 45,45\%. Kesesuaian pelaksanaan perkuliahan terhadap KKNI dilihat dari ketercapaian kemampuan mahasiswa terhadap KKNI pendidikan fisika yang memiliki persentase kemunculan sebesar 75,34\% dengan kategori sangat baik. Peran serta dosen terhadap ketercapaian kemampuan mahasiswa sesuai KKNI pendidikan fisika memiliki persentase kemunculan sebesar $55,01 \%$ dengan terkategori cukup. Kesesuaian penilaian perkuliahan terhadap KKNI yang dilihat dari indikator pada lembar penilaian berkategori baik, dengan persentase kemunculan sebesar $72,73 \%$.

\section{Implikasi}

Berdasarkan pembahasan yang telah diuraikan, implikasi dari penelitian ini di antaranya pembekalan perkuliahan hendaknya menuntut mahasiswa untuk melakukan observasi pembelajaran di sekolah walaupun sudah pernah dilakukan pada mata kuliah sebelumnya. Langkah ini bertujuan untuk memberikan gambaran yang luas tentang pembelajaran di sekolah. Pelaksanaan perkuliahan yang perlu ditingkatkan di antaranya peran serta dosen dalam memberikan alternatif metode maupun media yang digunakan dalam pembelajaran, serta memberikan evaluasi terhadap kemampuan mahasiswa yang telah dimunculkan oleh mahasiswa dalam praktik pembelajaran.

\section{Saran}

Berdasarkan hasil penelitian dan pembahasan diberikan saran untuk peningkatan kualitas pelaksanaan perkuliahan microteaching di prodi pendidikan fisika UIN Sunan Kalijaga Yogyakarta, di antaranya mahasiswa tetap melakukan observasi pembelajaran di sekolah sebagai bekal pelaksanaan perkuliahan microteaching walaupun telah dilakukan sebelumnya dalam kuliah strategi pembelajaran fisika. Untuk membedakannya, mahasiswa dapat melakukan observasi pembelajaran di sekolah yang lain.
Langkah ini akan memberikan gambaran tentang berbagai pembelajaran di sekolah dengan situasi yang berbeda; meskipun mahasiswa telah memiliki bekal pengetahuan tentang pelaksanaan pembelajaran melalui mata kuliah prasyarat. Mahasiswa calon pendidik lebih baik mendapatkan masukan mengenai strategi pembelajaran yang akan digunakan ketika terjun di lapangan sebagai pendidik maupun praktik pembelajaran lapangan. Dosen seharusnya menyusun SAP untuk perkuliahan microteaching, walaupun telah disediakan buku panduan praktik pembelajaran mikro. Langkah ini dilakukan agar dosen memahami langkah yang harus dilakukannya sesuai dengan tuntutan yang terdapat dalam buku panduan pembelajaran mikro yang telah disiapkan. Buku panduan perkuliahan mikro hendaknya selalu dikembangkan sesuai dengan kurikulum yang berlaku, serta disesuaikan dengan indikator KKNI.

\section{DAFTAR PUSTAKA}

Earl, K. \& Giles, D. (2011). Another look at assessment: Assessment in learning. New Zealand Journal of Teachers' Work, 6 (1), pp.11-20.

Erlina. (2012). Portofolio sebagai teknik alternatif penilaian dalam pembelajaran qiraah. Jurnal Al-Bayan, 4 (2), pp.1-10.

Ismail, S.A.A. (2011). Student teachers' microteaching experiences in a preservice english teacher education program. Journal of Language Teaching and Research, 2 (5), pp.1043-1051.

Mundilarto. (2010). Penilaian hasil belajar fisika. Yogyakarta: P2 IS FMIPA UNY.

Saban, A. \& Coklar, A. N. (2013). Pre-service teachers' opinions about the microteaching method in teaching practice classes. The Turkish Online Journal of Educational Technology, 12 (2), pp.234240.

La Sulo, S.L.; Paranto, S.; Soedirdjo. (1983). Pengajaran mikro. Jakarta: Depdikbud.

Sudiyatno \& Nuryanto, A. (2009). Model pembelajaran microteachng untuk calon guru smk rsbi. Diakses pad tanggal 21 Maret 2015, jam 20.20 WIB dari http://staff.uny.ac.id/system/files/penelitia n/Apri\%20Nuryanto,S.Pd.ST.,M.T./MOD EL\%20PEMBELAJARAN\%20MICROT EACHING.pdf. 
Sukaswanto. (2013). Mengaktifkan peran mahasiswa peserta pengajaran mikro dalam mensupervisi pelaksanaan pengajaran mikro. Jurnal Pendidikan Teknologi dan Kejuruan, 21 (3), pp.238-245.

Suwarna; Slamet, M.; Raharja, S. (2005). Pengajaran mikro. Yogyakarta: Tiara Wacana.

Tim UIN. (2011). Buku panduan praktik pembelajaran mikro. Yogyakarta: Fakultas Sains dan Teknologi UIN Sunan Kalijaga Yogyakarta.

Tim UNY. (2012). Buku panduan microteaching. Yogyakarta: Universitas Negeri Yogyakarta.
Juliantine, T. (2012). Penilaian dalam pendidikan jasmani. Jurnal Pendidikan Olahraga. 1 (8), pp.1-12.

Wati, U.A. (2014). Pelaksanaan pembelajaran yang kondusif dan efektif. Diakses pada tanggal 10 Maret 2015, jam 21.00 WIB dari

http://www.scribd.com/doc/197888403/ PELAKSANAAN-PEMBELAJARAN\# scribd

Asril, Z. (2010). Microteaching. Jakarta: Rajawali Pers. 